Tropical Journal of Pharmaceutical Research December 2016; 15 (12): 2693-2700

ISSN: $1596-5996$ (print); 1596-9827 (electronic)

(c) Pharmacotherapy Group, Faculty of Pharmacy, University of Benin, Benin City, 300001 Nigeria.

All rights reserved.

Available online at http://www.tjpr.org

Original Research Article

http://dx.doi.org/10.4314/tjpr.v15i12.22

\title{
Synthesis and evaluation of antioxidant and antimicrobial activities of Schiff base tin (II) complexes
}

\author{
Neelofar ${ }^{1}$, Nauman Ali ${ }^{1}$, Shabir Ahmad ${ }^{2}$, Naser M AbdEl-Salam ${ }^{3}$, Riaz Ullah ${ }^{4}$, \\ Robila Nawaz ${ }^{1}$ and Sohail Ahmad ${ }^{5}$ \\ ${ }^{1}$ Institute of Chemical Sciences, University of Peshawar, ${ }^{2}$ Department of Chemistry, Islamia College University, Peshawar \\ 25000, Pakistan, ${ }^{3}$ Riyadh Community College, King Saud University, Riyadh, Saudi Arabia, ${ }^{4}$ Department of Pharmacogonsoy, \\ College of Pharmacy King Saud University Saudi Arabia, ${ }^{5}$ Department of Chemistry, Qurtuba University of Science and \\ Information Technology Peshawar, Peshawar 25120, Pakistan
}

*For correspondence: Email: afridiriaz@yahoo.com

Revised accepted: 16 November 2016

\begin{abstract}
Purpose: To synthesize and evaluate Schiff base Tin (II) complexes for antioxidant and antimicrobial activities

Methods: The complexes of Tin (II) chloride with various Schiff base derivative of 2-Hydroxy-1naphthaldehyde $(H N)$ were synthesized and characterized by various physiochemical techniques, including elemental analysis, ultraviolet-visible (UV-Vis) spectrophotometry, Fourier transform infrared spectroscopy (FTIR), proton nuclear magnetic resonance $\left({ }^{1} H-N M R\right)$, carbon-13 nuclear magnetic resonance $\left({ }^{13} \mathrm{C}-\mathrm{NMR}\right)$, electron ionization mass spectrometry (EIMS) and conductance studies. Agarwell diffusion and agar-well dilution techniques were used for antimicrobial assessment. Evaluation of the antioxidant activity of the ligands and complexes was accomplished by DPPH radical scavenging assay.

Results: The results indicate coordination of deprotonated phenolic oxygen and nitrogen of azomethine with Tin (II) chloride led to the formation of stable complexes. The Tin (II) complexes showed good antimicrobial and antioxidant activities. Compounds ( $\mathrm{HNPA}$ and $\left[\mathrm{Sn}(\mathrm{HNPA}) \mathrm{Cl}_{2}\left(\mathrm{H}_{2} \mathrm{O}\right)_{2}\right)$ were noteworthy $(p<0.05)$ in this regard with antibacterial activity against Staphylococcus aureus, while $\left[\mathrm{Sn}(\mathrm{HNCA}) \mathrm{Cl}_{2}\left(\mathrm{H}_{2} \mathrm{O}\right)_{2}\right.$ and [Sn $(\mathrm{HNPT}) \mathrm{Cl}_{2}\left(\mathrm{H}_{2} \mathrm{O}\right)_{2}$ were active against Klebsiella pneumoniae..

Conclusion: All synthesized Schiff bases and their Tin (II) complexes showed high antimicrobial and antioxidant activities than their corresponding ligands.
\end{abstract}

Keywords: Schiff base, Ligand, Tin (II) complexes, Antimicrobial, Antioxidant, Deprotonated phenolic oxygen

Tropical Journal of Pharmaceutical Research is indexed by Science Citation Index (SciSearch), Scopus, International Pharmaceutical Abstract, Chemical Abstracts, Embase, Index Copernicus, EBSCO, African Index Medicus, JournalSeek, Journal Citation Reports/Science Edition, Directory of Open Access Journals (DOAJ), African Journal Online, Bioline International, Open-J-Gate and Pharmacy Abstracts

\section{INTRODUCTION}

Various metal complexes with bi- and tridentate Schiff bases containing nitrogen and oxygen donor atoms play important role in biological system [1]. Schiff base complexes have numerous applications, such as in the treatment of cancer, as bactericide agent, as antivirus agents, as fungicide agent anti- inflammatory and antipyretic agent in the treatment of diseases such as trypanosomiasis and jaundice and as analytical reagent [2-5]. The importance of metal ion in biological system as macrocyclic compounds is well established because of their catalytic behavior in a number of redox reactions of biological significance [6]. 2-Hydroxy-1naphthaldehyde Schiff base complexes are widely studied for its antimicrobial, catalytic and redox properties [7]. These results have led us to derive Schiff bases of 2-Hydroxyl-1- 
naphthaldehyde and its Sn (II) complexes. These complexes derived from 2-Hydroxyl-1naphthaldehyde were studied in detail for their applications in diverse areas such as antimicrobial and antioxidant activities.

\section{EXPERIMENTAL}

\section{Preparation of ligands and complexes}

Ligands and complexes were prepared according to the available methods in literature $[1,8]$. Their physical state, melting points, colour, and yield of ligands and complexes are shown in Table 1.

\section{Preparation of HNPA}

Equimolar ethanolic solution of 2-Hydroxy-1naphthaldehyde $(\mathrm{HN}) 0.01$ mole $(1.7218 \mathrm{~g})$ with 0.01 mole $(1.0814 \mathrm{~g})$ of o-phenylenediamine (PA) were refluxed with constant stirring for $40 \mathrm{~min}$. The precipitate formed were separated by sintered glass crucible which were dried in vacuum oven. The ligand was reprecipitated with ethanol.

\section{Preparation of HNPT}

Equimolar ethanolic solution of 2-Hydroxy-1naphthaldehyde (HN) 0.01 mole $(1.7218 \mathrm{~g})$ with 0.01 mole $(1.2758 \mathrm{~g})$ of 4 -Chloroaniline $(\mathrm{CA})$ were refluxed with constant stirring for $40 \mathrm{~min}$. The ligand was reprecipitated with ethanol.

\section{Preparation of HNPT}

Equimolar ethanolic solution of 2-Hydroxy-1naphthaldehyde $(\mathrm{HN}) 0.01$ mole $(1.7218 \mathrm{~g})$ with 0.01 mole $(1.079 \mathrm{~g})$ of $p$ - Toludine (PT) were refluxed with constant stirring for $40 \mathrm{~min}$. The precipitate formed was separated by sintered glass crucible which was dried in vacuum oven.

\section{Preparation of HNOT}

Equimolar ethanolic solution of 2-Hydroxy-1naphthaldehyde $(\mathrm{HN}) 0.01$ mole $(1.7218 \mathrm{~g})$ with
0.01 mole $(1.0814 \mathrm{~g})$ of o-Toludine (OT) were refluxed with constant stirring for $40 \mathrm{~min}$. The precipitate formed was separated by sintered glass crucible which was dried in vacuum oven.

\section{Preparation of complexes}

Equimolar $0.0025 \mathrm{~mole}$ ethanolic solution of ligands (HNPA, HNCA, HNPT, and HNOT) and 0.0025 mole $\mathrm{SnCl}_{2} .2 \mathrm{H}_{2} \mathrm{O}$ were refluxed with constant stirring for $2 \mathrm{~h}$. The precipitate formed was separated by filtering through sintered glass crucible washed with ethanol for the removal of non-reacted material afterwards samples were dried in vacuum oven.

\section{Antibacterial assay}

All synthesized Schiff bases and their Tin (II) complexes were screened in vitro for their antibacterial activity against Gram-negative (Klebsiella pneumoniae and Escherichia coli) and Gram-positive (Staphylococcus aureus, Staphylococcus epidermidis and Bacillus subtilis) bacterial strains by the agar-well diffusion method [9].

\section{Antifungal assay}

Synthesized Schiff bases and their Tin (II) complexes were investigated for antifungal activity against three fungal strains, i.e. Aspergillus niger, Aspergillus flavus and Alternaria solani by using the agar tube dilution method [10]. Nutrient agar was used for culturing of fungal strains. Nutrient agar media $(28 \mathrm{~g} / 1000$ $\mathrm{mL}$ ) was prepared in $\mathrm{dH}_{2} \mathrm{O}$ and sterilized in an autoclave for $15 \mathrm{~min}$ at $121{ }^{\circ} \mathrm{C}$ and 1.5 pounds pressure.

\section{Determination of antioxidant activity}

Antioxidant activities of the synthesized ligands, complexes as well as of the standard used were determined by the method of 1, 1-diphenyl-2picryl- hydrazyl (DPPH) free radical activity [11].

Table 1: Physical properties of the ligands and its complexes

\begin{tabular}{llcc}
\hline Compound & Physical state & Melting point & Color \\
\hline HNPA & Powder & $121-123.8$ & Brownish \\
{$\left[\mathrm{Sn}(\mathrm{HNPA}) \mathrm{Cl}_{2}\left(\mathrm{H}_{2} \mathrm{O}\right)_{2}\right]$} & Powder & 285 & Bright Orange \\
$\mathrm{HNCA}$ & Powder & 118.7 & Bright Yellow \\
{$\left[\mathrm{Sn}(\mathrm{HNCA}) \mathrm{Cl}_{2}\left(\mathrm{H}_{2} \mathrm{O}\right)_{2}\right]$} & Powder & 290 & Dull Yellow \\
$\mathrm{HNPT}$ & Powder & $90.2-91.3$ & Bright Yellow \\
{$\left[\mathrm{Sn}(\mathrm{HNPT}) \mathrm{Cl}_{2}\left(\mathrm{H}_{2} \mathrm{O}\right)_{2}\right]$} & Powder & 295 & Brown \\
HNOT & Powder & 86.1 & Yellow \\
{$\left[\mathrm{Sn}(\mathrm{HNOT}) \mathrm{Cl}_{2}\left(\mathrm{H}_{2} \mathrm{O}\right)_{2}\right]$} & Powder & 287 & Pale Yellowish \\
\hline
\end{tabular}




\section{RESULTS}

\section{Spectroscopic studies}

FTIR spectral bands of the relevant ligands and their tin complexes are given in Table 2.

In ligand HNPA and its complex [Sn(HNPA) $\left.\mathrm{Cl}_{2}\left(\mathrm{H}_{2} \mathrm{O}\right)_{2}\right]$, the $\cup \mathrm{C}=\mathrm{N}$ bands of free ligand at $1600 \mathrm{~cm}^{-1}$ are shifted to higher wave numbers $\left(1618,1653 \mathrm{~cm}^{-1}\right)$ in the spectra of the complex, indicating coordination of ligand to the tin ion via the azomethine nitrogen atom. The bands at 3471 and $3373 \mathrm{~cm}^{-1}$ are un-shifted in complex, indicating the free $\mathrm{N}-\mathrm{H}$ bond in complex. A new band in IR of complex appeared in the region of $561 \mathrm{~cm}^{-1}$, indicating the Sn-O bond in complex. In ligand HNCA and its complex [Sn(HNCA) $\mathrm{Cl}_{2}\left(\mathrm{H}_{2} \mathrm{O}\right)_{2}$ ], the $\cup \mathrm{C}=\mathrm{N}$ bands of free ligand at 1604 and $1558 \mathrm{~cm}^{-1}$ are shifted to higher wave numbers $\left(1618,1593 \mathrm{~cm}^{-1}\right)$ in the spectra of the complex, indicating coordination of ligand to the tin ion via the azomethine nitrogen atom. A band at $3028 \mathrm{~cm}^{-1}$ for hydrogen bond by $\mathrm{OH}$ group is shifted to $3061 \mathrm{~cm}^{-1}$, indicating the deprotonation of $-\mathrm{OH}$ and its involvement in coordination with metal ion. A new band in IR of complex appeared in the region of $537 \mathrm{~cm}^{-1}$, indicating the $\mathrm{Sn}-\mathrm{O}$ bond in complex. In ligand HNPT and its complex [ $\mathrm{Sn}(\mathrm{HNPT}) \mathrm{Cl}_{2}\left(\mathrm{H}_{2} \mathrm{O}\right)_{2}$ ] the $u$ $\mathrm{C}=\mathrm{N}$ bands of free ligand at 1618 and $1581 \mathrm{~cm}^{-1}$ are shifted to higher wave numbers $(1622,1593$ $\mathrm{cm}^{-1}$ ) in the spectra of the complex, indicating coordination of ligand to the tin ion via the azomethine nitrogen atom. A band at $3028 \mathrm{~cm}^{-1}$ for hydrogen bonded $\mathrm{OH}$ group is shifted to 3061 $\mathrm{cm}^{-1}$, indicating the deprotonation of $\mathrm{O}-\mathrm{H}$ and its involvement in coordination with metal ion. A new band in IR of complex appeared in the region of $536 \mathrm{~cm}^{-1}$, indicating the Sn-O bond in complex. In ligand $\mathrm{HNOT}$ and its complex $\left[\mathrm{Sn}(\mathrm{HNOT}) \mathrm{Cl}_{2}\left(\mathrm{H}_{2} \mathrm{O}\right)_{2}\right]$, the $\cup \mathrm{C}=\mathrm{N}$ bands of free ligand at $1610 \mathrm{~cm}^{-1}$ are shifted to higher wave numbers $\left(1622 \mathrm{~cm}^{-1}\right)$ in the spectra of the complex, indicating coordination of ligand to the tin ion via the azomethine nitrogen atom. A new band in IR of complex appeared in the region of $543 \mathrm{~cm}^{-1}$, indicating the Sn-O bond in complex. DMSO-d6 used as solvent for Proton NMR study. The ligand "exhibited signals that have been identified from the integration curve and found to be equivalent to the total number of protons deduced from their proposed structures. These were compared with the reported signals of known identical compounds data". The "HNMR data of the four Schiff bases studied are summarized in Table 3.

The phenolic hydroxyl proton in all structures appears in the range of 15-16 ppm. The azomethine protons appear in the range of 8.4 $9.6 \mathrm{ppm}$ which is characteristics of these protons. Signals in the region $7.0-7.9 \mathrm{ppm}$ were assigned to the aromatic protons.

Table 2: FTIR data for ligands and its complexes

\begin{tabular}{|c|c|c|c|c|c|}
\hline \multirow[t]{2}{*}{ Compound } & \multicolumn{5}{|c|}{ IR spectra $\left(\mathrm{cm}^{-1}\right)$} \\
\hline & $v(\mathrm{NH})$ & $v(\mathrm{OH})$ & $v(C=N)$ & $v(C-H)$ & $v(\mathrm{Sn}-\mathrm{O})$ \\
\hline HNPA & 3471,3373 & --.---- & 1600 & $1485-1406$ & -------- \\
\hline$\left[\mathrm{Sn}(\mathrm{HNPA}) \mathrm{Cl}_{2}\left(\mathrm{H}_{2} \mathrm{O}\right)_{2}\right]$ & 3471,3373 & -------- & 1618,1653 & $1485-1406$ & 561 \\
\hline HNCA & ------- & 3028 & 1604,1588 & $1485-1406$ & ---- \\
\hline$\left[\mathrm{Sn}(\mathrm{HNCA}) \mathrm{Cl}_{2}\left(\mathrm{H}_{2} \mathrm{O}\right)_{2}\right]$ & -------- & 3061 & 1618,1593 & $1485-1406$ & 537 \\
\hline HNPT & -------- & 3028 & 1618,1581 & $1485-1406$ & ------ \\
\hline$\left[\mathrm{Sn}(\mathrm{HNPT}) \mathrm{Cl}_{2}\left(\mathrm{H}_{2} \mathrm{O}\right)_{2}\right]$ & -------- & 3061 & 1622,1593 & $1485-1406$ & 536 \\
\hline HNOT & -------- & -------- & 1610 & $1485-1406$ & ------ \\
\hline$\left[\mathrm{Sn}(\mathrm{HNOT}) \mathrm{Cl}_{2}\left(\mathrm{H}_{2} \mathrm{O}\right)_{2}\right]$ & -------- & -------- & 1622 & $1485-1406$ & 543 \\
\hline
\end{tabular}

Table 3: ${ }^{1} \mathrm{H}$ NMR Spectral Data $(\bar{\delta}, \mathrm{ppm})$ of ligands and complexes

\begin{tabular}{|c|c|c|c|c|c|}
\hline \multirow[b]{2}{*}{ Compound } & \multicolumn{5}{|c|}{ 'H NMR Spectral Data (ס, ppm) } \\
\hline & $-H C=N$ & $-\mathrm{OH}$ & $-\mathrm{CH}_{3}$ & $\begin{array}{l}\text { Aromatic } \\
\text { hydrogen }\end{array}$ & $-\mathrm{NH}_{2}$ \\
\hline HNPA & 9.6 & 15.6 & 2.4 & $6.8-7.9$ & 5.1 \\
\hline$\left[\mathrm{Sn}(\mathrm{HNPA}) \mathrm{Cl}_{2}\left(\mathrm{H}_{2} \mathrm{O}\right)_{2}\right]$ & 10.11 & ---- & 2.3 & $7.2-7.9$ & ----- \\
\hline HNCA & 9.64 & 15.53 & 2.4 & $7.0-7.9$ & ----- \\
\hline$\left[\mathrm{Sn}(\mathrm{HNCA}) \mathrm{Cl}_{2}\left(\mathrm{H}_{2} \mathrm{O}\right)_{2}\right]$ & 9.66 & 15.56 & 2.3 & $7.0-8.5$ & ----- \\
\hline HNPT & 9.61 & 15.9 & 2.3 & 6.9-7.9 & ---- \\
\hline$\left[\mathrm{Sn}(\mathrm{HNPT}) \mathrm{Cl}_{2}\left(\mathrm{H}_{2} \mathrm{O}\right)_{2}\right]$ & 9.62 & 15.8 & 2.2 & $6.7-7.8$ & ----- \\
\hline HNOT & 9.63 & 16 & 2.4 & $6.9-7.9$ & ---- \\
\hline$\left[\mathrm{Sn}(\mathrm{HNOT}) \mathrm{Cl}_{2}\left(\mathrm{H}_{2} \mathrm{O}\right)_{2}\right]$ & 9.66 & 15.5 & 2.4 & 7.0-7.9 & ---- \\
\hline
\end{tabular}


Three protons of the methyl group in the ligands HNPT and HNOT appear in the range of $2.3-2.4$ ppm. Signal of the two protons of $\mathrm{NH}_{2}$ - group in the ligand HNPA appears at $5.12 \mathrm{ppm}$. The signals for azomethine proton appear in the range of 9.61-9.94 ppm for ligands shift downfield in the spectra of Tin (II) complexes. "The de-shielding is probably due to the donation of the lone pair of electrons on the azomethine nitrogen to tin, resulting in the formation of a coordinate bond". The signal for one proton in the range of $15-16 \mathrm{ppm}$ for the ligands corresponds to the $-\mathrm{OH}$ group attached to aromatic system. The signals shifts downfield in the spectra of the complexes

$\left[\mathrm{Sn}(\mathrm{HNCA}) \mathrm{Cl}_{2}\left(\mathrm{H}_{2} \mathrm{O}\right)_{2}\right]$, $\left[\mathrm{Sn}(\mathrm{HNPA}) \mathrm{Cl}_{2}\left(\mathrm{H}_{2} \mathrm{O}\right)_{2}\right.$ ] and [Sn(HNOT) $\mathrm{Cl}_{2}\left(\mathrm{H}_{2} \mathrm{O}\right)_{2}$ ] showing the coordination of oxygen with tin metal without the deprotonation of the $-\mathrm{OH}$ group. In the case of $\left[\mathrm{Sn}(\mathrm{HNPA}) \mathrm{Cl}_{2}\right.$ ] complex the $-\mathrm{OH}$ signal disappears indicating the deprotonation of oxygen atoms of the ligand on complexation. The multiplets between $6.8-8.5 \mathrm{ppm}$ in the spectra of ligands are assigned to the naphthylidene group protons. These multiplets have downfield shift in the spectra of the complexes attributed to increased conjugation upon complex formation. In all the complexes new peak appear in the region of 3.0-3.4 ppm were assigned for coordinated water ${ }^{13} \mathrm{C}$ NMR Spectra of the four ligands were recorded in DMSO-d6 and these spectra also support the authenticity of the proposed structures (Table 4).

The signals observed at $167-171.8 \mathrm{ppm}$ are due to azomethine carbons. The peak for the $-\mathrm{OH}$ group appears at 154.5-156.6 ppm. The aromatic carbon directly attached with azomethine carbon shows peak at 39.2-39.7 ppm. The aromatic carbon directly attached with azomethine nitrogen shows peak at $141-143.3 \mathrm{ppm}$. The methyl carbons in the ligands HNPT and HNOT appears in the range of $17.7-20.5 \mathrm{ppm}$. The carbon having chlorine atom in I-2 showed signal at $130.63 \mathrm{ppm}$. Carbon attached with the unreacted $-\mathrm{NH}_{2}$ group shows signal at $141.76 \mathrm{ppm}$. All other aromatic carbons showed peak in the range of $121-133 \mathrm{ppm}$. In the ${ }^{13} \mathrm{C}$-NMR spectra of the ligands, the signals observed in the range of 167 - $171.8 \mathrm{ppm}$ are due to azomethine carbons.

These signals shift ( $\delta 168.9-169.4 \mathrm{ppm}$ ) in the case of Tin (II) complexes, indicating the coordination of azomethine nitrogen to the tin. Signals in the range of $\delta 154-157.4 \mathrm{ppm}$ are assigned to the aromatic carbons attached to the $-\mathrm{OH}$ group in various ligands. The shifts were observed in these signals ( $\delta$ 154-159.3 ppm) when the free ligands are coordinated to the tin atom indicating the involvement of $-\mathrm{OH}$ group in complex formation. In the ${ }^{13} \mathrm{C}$-NMR spectra of the ligands, the signals observed in the range of $\delta$ $141.08-143.38 \mathrm{ppm}$ are due to aromatic carbons attached to azomethine nitrogen. The shift in these signal are observed in the range of $\delta 141.10$ - $157.41 \mathrm{ppm}$.

\section{Elemental analysis and atomic absorption data}

"The close agreement in the calculated and found values of the elemental analysis" shows the formation of ligands (HNPA,HNCA, HNPT and $\mathrm{HNOT}$ ) and complexes ([Sn(HNPA) $\left.\mathrm{Cl}_{2}\left(\mathrm{H}_{2} \mathrm{O}\right)_{2}\right], \quad\left[\mathrm{Sn}(\mathrm{HNCA}) \mathrm{Cl}_{2}\left(\mathrm{H}_{2} \mathrm{O}\right)_{2}\right]$, [Sn(HNPT) $\mathrm{Cl}_{2}\left(\mathrm{H}_{2} \mathrm{O}\right)_{2}$ ] and [Sn(HNOT) $\left.\mathrm{Cl}_{2}\left(\mathrm{H}_{2} \mathrm{O}\right)_{2}\right]$ ) as seen in Table 5. The atomic absorption data for tin metal is also shown in Table 5. The data establishing the general formula of complexes is $\left[\mathrm{Sn}(\mathrm{L}) \mathrm{Cl}_{2} \mathrm{nH}_{2} \mathrm{O}\right.$ ] "where $\mathrm{L}$ is ligand, and $\mathrm{n}=1$ or 2 , is the number of coordinated water".

Table $4:{ }^{13} \mathrm{C}-\mathrm{NMR}$ spectral data $(\delta, \mathrm{ppm})$ for ligands and its complexes

\begin{tabular}{|c|c|c|c|c|c|}
\hline \multirow[b]{2}{*}{ Compound } & \multicolumn{5}{|c|}{${ }^{13} \mathrm{C}-\mathrm{NMR}$ spectral data ( $\left.\delta, \mathrm{ppm}\right)$} \\
\hline & $-H C=N$ & $\begin{array}{l}\text { Aromatic } \\
\text { carbon } \\
\text { attached } \\
\text { with -OH } \\
\text { group }\end{array}$ & $\begin{array}{c}\text { Aromatic } \\
\text { carbon } \\
\text { attached with } \\
\text { azomethine } \\
\text { Nitrogen }\end{array}$ & $\begin{array}{l}\text { Aromatic carbon } \\
\text { attached with - } \\
\mathrm{NH}_{2} \text { group }\end{array}$ & $-\mathrm{CH}_{3}$ \\
\hline HNPA & 167.04 & 155.65 & 141.76 & 135.59 & 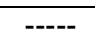 \\
\hline$\left[\mathrm{Sn}(\mathrm{HNPA}) \mathrm{Cl}_{2}\left(\mathrm{H}_{2} \mathrm{O}\right)_{2}\right]$ & 168.98 & 159.30 & 157.41 & $140.47,133.94$ & ----- \\
\hline HNCA & 169.37 & 156.59 & 143.38 & ----- & ----- \\
\hline$\left[\mathrm{Sn}(\mathrm{HNCA}) \mathrm{Cl}_{2}\left(\mathrm{H}_{2} \mathrm{O}\right)_{2}\right]$ & 169.21 & 156.64 & 143.43 & ----- & ----- \\
\hline HNPT & 170.82 & 154.59 & 141.08 & ----- & 20.54 \\
\hline$\left[\mathrm{Sn}(\mathrm{HNPT}) \mathrm{Cl}_{2}\left(\mathrm{H}_{2} \mathrm{O}\right)_{2}\right]$ & 170.75 & 154.65 & 141.54 & ----- & 20.54 \\
\hline HNOT & 171.80 & 154.49 & 142.09 & ----- & 38.67 \\
\hline$\left[\mathrm{Sn}(\mathrm{HNOT}) \mathrm{Cl}_{2}\left(\mathrm{H}_{2} \mathrm{O}\right)_{2}\right]$ & 169.46 & 156.66 & 143.39 & ----- & 39.0 \\
\hline
\end{tabular}

Table 5: Elemental analysis and atomic absorption data for ligands and complexes 


\begin{tabular}{|c|c|c|c|c|c|c|c|c|c|}
\hline \multirow{3}{*}{ Compound } & \multirow{3}{*}{$\begin{array}{l}\text { Molecular } \\
\text { formula }\end{array}$} & \multicolumn{8}{|c|}{ Elemental analysis and atomic absorption data } \\
\hline & & \multicolumn{3}{|c|}{$\% \mathrm{C}$} & \multicolumn{2}{|l|}{$\% \mathbf{N}$} & \multicolumn{2}{|l|}{$\% \mathrm{H}$} & \multirow{2}{*}{$\begin{array}{c}\% \text { Sn } \\
\text { Obs }\end{array}$} \\
\hline & & Cal & Obs & Cal & Obs & Cal & Obs & Cal & \\
\hline HNPA & $\mathrm{C}_{6} \mathrm{H}_{4}\left(\mathrm{NH}_{2}\right)_{2}$ & 80.75 & 78.79 & 11.63 & 10.64 & 4.84 & 4.84 & ----- & $\begin{array}{ll}---- \\
\end{array}$ \\
\hline$\left[\mathrm{Sn}(\mathrm{HNPA}) \mathrm{Cl}_{2}\left(\mathrm{H}_{2} \mathrm{O}\right)_{2}\right]$ & $\begin{array}{l}\mathrm{C}_{28} \mathrm{H}_{20} \mathrm{Cl}_{2} \mathrm{~N}_{2} \\
\mathrm{O}_{2} \mathrm{Sn} . \mathrm{H}_{2} \mathrm{O}\end{array}$ & 47.0 & 46.70 & 4.10 & 3.98 & 2.1 & 1.54 & 17.11 & 16.97 \\
\hline HNCA & $\mathrm{C}_{6} \mathrm{H}_{4} \mathrm{NH}_{2}$ & 74.47 & 73.96 & 4.97 & 4.91 & 2.99 & 2.48 & ---- & ----- \\
\hline$\left[\mathrm{Sn}(\mathrm{HNCA}) \mathrm{Cl}_{2}\left(\mathrm{H}_{2} \mathrm{O}\right)_{2}\right]$ & $\begin{array}{l}\mathrm{C}_{17} \mathrm{H}_{12} \mathrm{Cl}_{3} \mathrm{NO} \\
\text { Sn. } \mathrm{H}_{2} \mathrm{O}\end{array}$ & 40.94 & 40.30 & 2.90 & 2.70 & 2.5 & 1.96 & 10.99 & 10.78 \\
\hline HNPT & $\mathrm{CH}_{3} \mathrm{C}_{6} \mathrm{H}_{4} \mathrm{NH}_{2}$ & 86.73 & 86.26 & 5.4 & 5.31 & 3.36 & 3.47 & ---- & ---- \\
\hline$\left[\mathrm{Sn}(\mathrm{HNPT}) \mathrm{Cl}_{2}\left(\mathrm{H}_{2} \mathrm{O}\right)_{2}\right]$ & $\begin{array}{l}\mathrm{C}_{18} \mathrm{H}_{15} \mathrm{Cl}_{2} \mathrm{NO} \\
\text { Sn. } \mathrm{H}_{2} \mathrm{O}\end{array}$ & 45.77 & 45.14 & 3.10 & 2.89 & 2.9 & 2.36 & 21.96 & 21.56 \\
\hline HNOT & $\mathrm{CH}_{3} \mathrm{C}_{6} \mathrm{H}_{4} \mathrm{NH}_{2}$ & 82.73 & 82.14 & 5.36 & 5.28 & 3.36 & 3.91 & ----- & ----- \\
\hline$\left[\mathrm{Sn}(\mathrm{HNOT}) \mathrm{Cl}_{2}\left(\mathrm{H}_{2} \mathrm{O}\right)_{2}\right]$ & $\begin{array}{l}\mathrm{C}_{18} \mathrm{H}_{15} \mathrm{Cl}_{2} \mathrm{NO} \\
\text { Sn. } \mathrm{H}_{2} \mathrm{O}\end{array}$ & 45.77 & 45.35 & 3.10 & 2.84 & 2.9 & 2.31 & 21.96 & 21.52 \\
\hline
\end{tabular}

\section{Molar conductance}

In Table 6 the molar conductance data of synthesized complexes are given which indicate that all of them are non-electrolytic in nature in the solvent. Because in electrolytic complexes the anion bonded outside the coordination sphere with metal. Also low conductance results support the reality that the "Schiff bases are coordinated to the tin atom in their deprotonated anionic forms" and that the two chlorides ligands are also coordinated to the tin atom.

\section{Electronic spectra}

The electronic absorption spectra of ligands and their Sn (II) complexes in DMF solution were carried out in the range of $200-1000 \mathrm{~nm}$ at room temperature (Table 7).
There is a shift of the bands to longer $\lambda$ in spectra of all Sn (II) complexes is a good evidence of complex formation. The ligand HNPA chromophore $\mathrm{HC}=\mathrm{N}$ which absorbs at $270 \mathrm{~nm}$, due to $n-n^{*}$ transition of azomethine group. The shift to the longer wavelength at $310 \mathrm{~nm}$ in the spectra of tin (II) complex [ $\left.\mathrm{Sn}(\mathrm{HNPA}) \mathrm{Cl}_{2}\left(\mathrm{H}_{2} \mathrm{O}\right)_{2}\right]$ is a good evidence of complex formation and coordination of azomethine nitrogen in the complex. The complex absorption showed two sharp bands at $340 \mathrm{~nm}$ and $360 \mathrm{~nm}$ and these may be assigned as charge transfer bands. It has been reported that the metal is capable of forming $\mathrm{d} \Pi-\mathrm{p} \Pi^{*}$ bonds with ligands containing nitrogen as the donor atom. The Tin atom has its $5 \mathrm{~d}$ orbital completely vacant and hence $\mathrm{Sn}-\mathrm{N}$ bonding can take place by the acceptance of the lone pair of electrons from the nitrogen of the ligands.

Table 6: Molar conductance analysis of complexes

\begin{tabular}{|c|c|c|c|c|}
\hline Complex & Solvent & $\begin{array}{l}\text { Weight taken } \\
\text { (mg)/solvent } \\
\text { added ( } 40 \mathrm{~mL})\end{array}$ & $\begin{array}{c}\text { Molar } \\
\text { conductance } \\
\mathrm{Ohm}^{-1} \mathrm{~cm}^{2} \mathrm{~mol}^{-1}\end{array}$ & Inference \\
\hline$\left[\mathrm{Sn}(\mathrm{HNPA}) \mathrm{Cl}_{2}\left(\mathrm{H}_{2} \mathrm{O}\right)_{2}\right]$ & DMF & 1.8 & 2.5 & Non-electrolyte \\
\hline$\left[\mathrm{Sn}(\mathrm{HNCA}) \mathrm{Cl}_{2}\left(\mathrm{H}_{2} \mathrm{O}\right)_{2}\right]$ & DMF & 2.2 & 4.6 & Non- electrolyte \\
\hline$\left[\mathrm{Sn}(\mathrm{HNPT}) \mathrm{Cl}_{2}\left(\mathrm{H}_{2} \mathrm{O}\right)_{2}\right]$ & DMF & 2.1 & 5.3 & Non-electrolyte \\
\hline$\left[\mathrm{Sn}(\mathrm{HNOT}) \mathrm{Cl}_{2}\left(\mathrm{H}_{2} \mathrm{O}\right)_{2}\right]$ & DMF & 2.4 & 8.6 & Non- electrolyte \\
\hline
\end{tabular}

Table 7: Electronic spectral data of complexes

\begin{tabular}{lccc}
\hline Compound & Solvent & \multicolumn{2}{c}{ Absorption maximum $(\mathbf{n m})$} \\
\hline $\mathrm{HNPA}$ & DMF & 270 & ------ \\
{$\left[\mathrm{Sn}(\mathrm{HNPA}) \mathrm{Cl}_{2}\left(\mathrm{H}_{2} \mathrm{O}\right)_{2}\right]$} & DMF & $310,340-360$ & ----- \\
$\mathrm{HNCA}$ & $\mathrm{DMF}$ & 220,240 & 450 \\
{$\left[\mathrm{Sn}(\mathrm{HNCA}) \mathrm{Cl}_{2}\left(\mathrm{H}_{2} \mathrm{O}\right)_{2}\right]$} & $\mathrm{DMF}$ & 230,250 & ------ \\
$\mathrm{HNPT}$ & $\mathrm{DMF}$ & 360 & 400,440 \\
{$\left[\mathrm{Sn}(\mathrm{HNPT}) \mathrm{Cl}_{2}\left(\mathrm{H}_{2} \mathrm{O}\right)_{2}\right]$} & $\mathrm{DMF}$ & ----- & 390 \\
$\mathrm{HNOT}$ & $\mathrm{DMF}$ & 320,360 & 430,460 \\
{$\left[\mathrm{Sn}(\mathrm{HNOT}) \mathrm{Cl}_{2}\left(\mathrm{H}_{2} \mathrm{O}\right)_{2}\right]$} & $\mathrm{DMF}$ & 310,370 & 460 \\
\hline
\end{tabular}

In the electronic spectra of the ligand HNCA, a band at $220 \mathrm{~nm}$ was observed which may be assigned to $1 \mathrm{~B}$ band of phenyl ring. The electronic spectra of the ligand consist of a band 
at $240 \mathrm{~nm}$ have been assigned $\theta-\theta^{*}$ transitions within the benzenoid ring. This band remains almost unchanged in the electronic spectra of the complex $\left[\mathrm{Sn}(\mathrm{HNCA}) \mathrm{Cl}_{2}\left(\mathrm{H}_{2} \mathrm{O}\right)_{2}\right]$. The UV/Vis spectrum of the ligand HNPT showed three bands. One is at $360 \mathrm{~nm}$ which is assigned to $\mathrm{n}$ $\pi^{*}$ transition. Second band at $400 \mathrm{~nm}$ is due to n$\pi^{*}$ electronic transitions of azomethine. In Sn (II) complex [Sn(HNPT) $\mathrm{Cl}_{2}\left(\mathrm{H}_{2} \mathrm{O}\right)_{2}$ ] a band appears at $390 \mathrm{~nm}$ is possibly due to the polarization in $\mathrm{C}=\mathrm{N}$ bond caused by the metal-ligand electronic interaction. The electronic spectra of the free ligand HNOT, the bands recorded at $320 \mathrm{~nm}$ and $360 \mathrm{~nm}$ are assigned to $n-\pi^{*}$ transitions of azomethine group. These bands shifted to higher wavelength on coordination through azomethine nitrogen in the complex [Sn(HNOT) $\mathrm{Cl}_{2}\left(\mathrm{H}_{2} \mathrm{O}\right)_{2}$ ]. The band at $310 \mathrm{~nm}$ are due to $\pi-\pi^{*}$ transitions within the azomethine. The band at $370 \mathrm{~nm}$ in complex is possibly due to polarization of the $\mathrm{C}=\mathrm{N}$ bond caused by the metal-ligand interaction.

\section{Antimicrobial activity}

The antimicrobial activities results clearly showed that the synthesized ligands and their tin comp lexes are biological active as shown in Table 8 and Table 9. From the data obtained, it is evident that some of these complexes exhibited significant activity $(p<0.05)$ against the tested organisms. Compound [Sn(HNCA)Cl ${ }_{2}\left(\mathrm{H}_{2} \mathrm{O}\right)_{2}$ ] showed maximum activity against Gram-negative bacterial species (Klebsiella pneumoniae and Escherichia coli). [Sn(HNPA) $\mathrm{Cl}_{2}\left(\mathrm{H}_{2} \mathrm{O}\right)_{2}$ ] showed the highest antibacterial activity against Grampositive (Staphylococcus aureus, Staphylococcus epidermidis and Bacillus subtilis) bacteria. The antifungal activity results showed that [Sn(HNPA)Cl ${ }_{2}\left(\mathrm{H}_{2} \mathrm{O}\right)_{2}$ ], [Sn(HNOT) $\mathrm{Cl}_{2}\left(\mathrm{H}_{2} \mathrm{O}\right)_{2}$ ] and HNPT showed highest activity against Aspergillus niger, Aspergillus flavus and Alternaria solani respectively.

Table 8: Antibacterial activity of ligands and its Tin (II) complexes

\begin{tabular}{|c|c|c|c|c|c|}
\hline \multirow{2}{*}{ Compound } & \multicolumn{5}{|c|}{ Zone of Inhibition (mm) \pm SEM } \\
\hline & $\begin{array}{c}\text { Klebsiella } \\
\text { pneumoniae }\end{array}$ & $\begin{array}{c}\text { Escherichia } \\
\text { coli }\end{array}$ & $\begin{array}{c}\text { Staphylococcus } \\
\text { aureus }\end{array}$ & $\begin{array}{c}\text { Staphylococcus } \\
\text { epidermidis }\end{array}$ & $\begin{array}{l}\text { Bacillus } \\
\text { subtilis }\end{array}$ \\
\hline HNPA & $13 \pm 0.78$ & $12 \pm 0.54$ & $17 \pm 0.65$ & $03 \pm 0.17$ & $13 \pm 0.23$ \\
\hline$\left[\mathrm{Sn}(\mathrm{HNPA}) \mathrm{Cl}_{2}\left(\mathrm{H}_{2} \mathrm{O}\right)_{2}\right]$ & $15 \pm 0.43$ & $14 \pm 0.69$ & $18 \pm 0.45$ & $15 \pm 0.53$ & $14 \pm 0.33$ \\
\hline HNCA & $06 \pm 0.61$ & $15 \pm 0.47$ & $03 \pm 0.19$ & $04 \pm 0.12$ & $02 \pm 0.13$ \\
\hline$\left[\mathrm{Sn}(\mathrm{HNCA}) \mathrm{Cl}_{2}\left(\mathrm{H}_{2} \mathrm{O}\right)_{2}\right]$ & $20 \pm 0.23$ & $18 \pm 0.66$ & $06 \pm 0.21$ & $06 \pm 0.24$ & $03 \pm 0.10$ \\
\hline HNPT & $15 \pm 0.54$ & $12 \pm 0.34$ & $04 \pm 0.14$ & $05 \pm 0.27$ & $02 \pm 0.08$ \\
\hline$\left[\mathrm{Sn}(\mathrm{HNPT}) \mathrm{Cl}_{2}\left(\mathrm{H}_{2} \mathrm{O}\right)_{2}\right]$ & $17 \pm 0.73$ & $15 \pm 0.41$ & $07 \pm 0.41$ & $07 \pm 0.33$ & $03 \pm 0.10$ \\
\hline HNOT & $15 \pm 0.45$ & $04 \pm 0.24$ & $05 \pm 0.11$ & $03 \pm 0.12$ & $05 \pm 0.21$ \\
\hline$\left[\mathrm{Sn}(\mathrm{HNOT}) \mathrm{Cl}_{2}\left(\mathrm{H}_{2} \mathrm{O}\right)_{2}\right]$ & $19 \pm 0.87$ & $06 \pm 0.12$ & $06 \pm 0.15$ & $04 \pm 0.10$ & $06 \pm 0.13$ \\
\hline Standard & $24 \pm 0.92$ & $25 \pm 0.77$ & $24 \pm 0.56$ & $26 \pm 0.67$ & $24 \pm 0.54$ \\
\hline
\end{tabular}

Table 9: Antifungal activity of ligands and their Tin (II) complexes

\begin{tabular}{lccc}
\hline \multirow{2}{*}{ Compound } & \multicolumn{3}{c}{ Growth Inhibition ( \pm SEM, \%) } \\
\cline { 2 - 4 } & $40 \pm 0.81$ & $\begin{array}{c}\text { Aspergillus } \\
\text { flavus }\end{array}$ & $\begin{array}{c}\text { Alternaria } \\
\text { solani }\end{array}$ \\
\hline $\mathrm{HNPA}$ & $60 \pm 0.50$ & $10 \pm 0.65$ & $20 \pm 0.26$ \\
{$\left[\mathrm{Sn}(\mathrm{HNPA}) \mathrm{Cl}_{2}\left(\mathrm{H}_{2} \mathrm{O}\right)_{2}\right]$} & $10 \pm 0.23$ & $30 \pm 0.73$ & $30 \pm 0.45$ \\
$\mathrm{HNCA}$ & $15 \pm 0.54$ & $06 \pm 0.24$ & $15 \pm 0.72$ \\
{$\left[\mathrm{Sn}(\mathrm{HNCA}) \mathrm{Cl}_{2}\left(\mathrm{H}_{2} \mathrm{O}\right)_{2}\right]$} & $02 \pm 0.20$ & $25 \pm 0.63$ & $30 \pm 0.77$ \\
$\mathrm{HNPT}$ & $35 \pm 0.74$ & $03 \pm 0.10$ & $35 \pm 0.56$ \\
{$\left[\mathrm{Sn}(\mathrm{HNPT}) \mathrm{Cl}_{2}\left(\mathrm{H}_{2} \mathrm{O}\right)_{2}\right]$} & $20 \pm 0.43$ & $20 \pm 0.46$ & $20 \pm 0.49$ \\
$\mathrm{HNOT}$ & $45 \pm 0.33$ & $30 \pm 0.73$ & $30 \pm 0.53$ \\
{$\left[\mathrm{Sn}(\mathrm{HNOT}) \mathrm{Cl}_{2}\left(\mathrm{H}_{2} \mathrm{O}\right)_{2}\right]$} & 0 & $33 \pm 0.82$ & $32 \pm 0.49$ \\
Standard & & 0 & 0 \\
\hline
\end{tabular}


Table 10: Antioxidant activity of ligands and its Tin (II) complexes

\begin{tabular}{lcc}
\hline Compound & $\mathbf{E C}_{50}(\mathbf{p p m})$ & Inference \\
\hline HNPA & -327.18 & Inactive \\
[Sn(HNPA) $\left.\mathrm{Cl}_{2}\left(\mathrm{H}_{2} \mathrm{O}\right)_{2}\right]$ & 220.94 & Antioxidant \\
HNCA & -23233.85 & Inactive \\
{$\left[\mathrm{Sn}(\mathrm{HNCA}) \mathrm{Cl}_{2}\left(\mathrm{H}_{2} \mathrm{O}\right)_{2}\right]$} & 387.71 & Antioxidant \\
HNPT & -1139.9 & Inactive \\
[Sn(HNPT) $\left.\mathrm{Cl}_{2}\left(\mathrm{H}_{2} \mathrm{O}\right)_{2}\right]$ & 208.87 & Antioxidant \\
HNOT & 47.447 & Antioxidant \\
{$\left[\mathrm{Sn}(\mathrm{HNOT}) \mathrm{Cl}_{2}\left(\mathrm{H}_{2} \mathrm{O}\right)_{2}\right]$} & -175.25 & Inactive \\
\hline
\end{tabular}

\section{Antioxidant activity}

Significant antioxidant potential was recorded for ligands and their Tin (II) complexes. Antioxidant activity for complexes was active $\mathrm{EC}_{50}$ values are given in Table 10. Lower $E_{50}$ value showed higher antioxidant potential of all the tested samples.

\section{DISCUSSION}

Schiff base complexes catch researcher's interest due to its significant role in biologically important species and in the bioinorganic chemistry development [12,13]. The carbon having chlorine atom in $1-2$ showed signal at $130.63 \mathrm{ppm}$. Carbon attached with the unreacted $-\mathrm{NH}_{2}$ group shows signal at $141.76 \mathrm{ppm}$. All other aromatic carbons showed peak in the range of $121-133 p p m$. In the ${ }^{13} \mathrm{C}-\mathrm{NMR}$ spectra of the ligands, the signals observed in the range of $167-171.8 \mathrm{ppm}$ are due to azomethine carbons. These signals shift $(\delta 168.9-169.4$ $\mathrm{ppm}$ ) in the case of tin (II) complexes, indicating the coordination of azomethine nitrogen to the tin [14].

Low conductance data also support the fact that the Schiff bases are coordinated to the tin atom in their deprotonated anionic forms and that the two chlorides ligands are also coordinated to the tin atom [15]. The tin atom has its $5 d$ orbital completely vacant and hence $\mathrm{Sn}-\mathrm{N}$ bonding can take place by the acceptance of the lone pair of electrons from the nitrogen of the ligands [16]. In the electronic spectra of the ligand HNCA, a band at $220 \mathrm{~nm}$ was observed which may be assigned to $1 \mathrm{~B}$ band of phenyl ring [17].

Several Schiff base metal complexes were investigated for antibacterial assessment and revealed that metal complexes are more active as compared to free ligands [18]. Antioxidant activity for complexes was active at various $\mathrm{EC}_{50}$ values. Lower $\mathrm{EC}_{50}$ value was attributed to higher antioxidant potential of all the tested samples [19].

\section{CONCLUSION}

The complexes synthesized from 2-Hydroxyl-1naphthaldehyde exhibit various biological activities. They possess potentials that can be further developed to exert strong antimicrobial and antioxidant activities.

\section{DECLARATIONS}

\section{Acknowledgement}

The authors are thankful to the Deanship of Scientific Research, King Saud University, Riyadh, Saudi Arabia, for funding the work through the Research Group Project no. RGP210.

\section{Conflict of Interest}

No conflict of interest associated with this work.

\section{Contribution of Authors}

The authors declare that this work was done by the authors named in this article and all liabilities pertaining to claims relating to the content of this article will be borne by them.

\section{Open Access}

This is an Open Access article that uses a funding model which does not charge readers or their institutions for access and distributed under the terms of the Creative Commons Attribution License (http://creativecommons.org/licenses/by 14.0) and the Budapest Open Access Initiative (http://www.budapestopenaccessinitiative.org/rea d), which permit unrestricted use, distribution, and reproduction in any medium, provided the original work is properly credited.

\section{REFERENCES}

1. Singh BK, Prakash A, Rajour HK, Bhojak N, Adhikari D. Spectroscopic characterization and biological activity of $\mathrm{Zn}(\mathrm{II}), \mathrm{Cd}(\mathrm{II}), \mathrm{Sn}(\mathrm{II})$ and $\mathrm{Pb}(\mathrm{II})$ complexes with Schiff base derived from pyrrole-2- carboxaldehyde and 2amino phenol. Spectrochim Acta Part A: Molec Biomolec Spectros. 2010; 76: 376-383.

2. Neelakantana MA, Dharmarajaa, FR, Johnsonrajaa $S$, Jeyakumarb $M$, Sankaranarayana $P$. Spectral characterization, cyclic voltammetry, morphology, biological activities and DNA cleaving studies of amino acid Schiff base metal (II) complexes. Spectrochim Acta Part A: Molec Biomolec Spectrosc. 2008; 71: 15991609. 
3. Khedr AM, Jadon S, Kumar V. Synthesis, spectral analysis, and molecular modeling of bioactive Sn (II)complexes with oxadiazole Schiff bases. J Coordination Chem. 2011; 64(8): 1351-1359.

4. Ramirez-Jimenez A, Gomez, E, Hernandez S. Pentaand heptacoordinated tin (IV) compounds derived from pyridine Schiff bases and 2-pyridine carboxylate: Synthesis and structural characterization. J Organometallic Chem. 2009; 694(18): 2965-2975.

5. Omar MM, Mohamed GG, Hindy AMM. Transitional complexes of heterocyclic Schiff base Biological activity, spectroscopic and thermal characterization. J Thermal Ana Calorimet. 2006; 86(2): 315-325.

6. Kripa S, Sonal A, Sangita, G. Antifungal, antibacterial and antifertility activities of biologically active macrocyclic complexes of Tin (II). Internat J ChemTech Res. 2013; 5(1): 456-463.

7. Prabhakaran R, Krishnan V, Pasumpon K, Sukanya D, Wendel E, Jayabalakrishnan C, Bertagnolli $H$, Natarajan K. Preparation, spectral characterization, electrochemistry, EXAFS, antibacterial and catalytic activity of new ruthenium (III) complexes containing ONS donor ligands with tripheny/phosphine/arsine. App Organomet Chem. 2006; 20(3): 203-213.

8. Lal RA, Chanu OB, Borthakur R, Asthana M, Kumar A, $D e A K$. Synthesis and characterization of molybdenum $(V, \quad$ VI) complexes derived from bis (2-hydroxy-1naphthaldehyde) malonoyldihydrazone. J Coordination Chem. 2011; 64(8): 1393-1410.

9. Chohan ZH, Sumrra SH, Youssoufi MH, Hadda TB. Metal based biologically active compounds: design, synthesis, and antibacterial/antifungal/cytotoxic properties of diazole-derived Schiff bases and their oxovanadium (IV) complexes. European J Med Chem. 2010; 45(7): 27392747.

10. Sirajuddin M, Ali S, Haider Ali, Shah NA, Shah A, Khan MR. Synthesis, characterization, biological screenings and interaction with calf thymus DNA as well as electrochemical studies of adducts formed by azomethine [2-((3, 5-dimethylphenylimino) methyl) phenol] and organotin (IV) chlorides. Polyhedron. 2012; 40(1): 19-31.
11. Nooman A, Khalaf AKS, Atif AO, Zaha EA, Husni $F$. Antioxidant activity of some common plants. Turk $J$ Biol. 2008; 32: 51-55.

12. Shakir M, Shahid $N$, Sami N, Azam M, Khan AU. Synthesis, spectroscopic characterization and comparative DNA binding studies of Schiff base complexes derived from l-leucine and glyoxal. Spectrochim Acta A: Molec Biomolec Spectrosc. 2011; 82(1): 31-36.

13. Singh $H$ L, Singh JB, Sachedva H. Synthesis, spectroscopic and antimicrobial studies of lead (II) complexes of schiff bases derived from amino acids and isatins. Spectroscopy Lett. 2013; 46(4): 286-296.

14. Varshney A, Tandon JP. Synthesis and characteristic studies of Tin (II) and Tin (IV) complexes of macrocyclic Schiff base. Polyhed. 1986; 5(11): 1853-1855.

15. Ali MA, Mirza AH, Malai Haniti SAH, Bernhardt PV. Diphenyltin (IV) complexes of the 2quinolinecarboxaldehyde Schiff bases of S-methyl- and S-benzyldithiocarbazate (Hqaldsme and Hqaldsbz): $X$ ray crystal structures of Hqaldsme and two conformers of its diphenyltin (IV) complex. Polyhed. 2005; 24(3): 383-390.

16. Singh HL. Synthesis and characterization of tin (II) complexes of fluorinated Schiff bases derived from amino acids. Spectrochim Acta Part A: Molec Biomolec Spectrosc. 2010; 76(2): 253-258.

17. Singh RV, Chaudhary $P$, Chauhan S, Swami $M$. Microwave-assisted synthesis, characterization and biological activities of organotin (IV) complexes with some thio Schiff bases. Spectrochim Acta Part A: Molec Biomolec Spectrosc. 2009; 72(2): 260-268.

18. Ejidike IP, Ajibade PA. Synthesis, Characterization, Antioxidant, and Antibacterial Studies of Some Metal(II) Complexes of Tetradentate Schiff Base Ligand: (4E)-4$[(2-\{(E)-[1-(2,4-$

Dihydroxyphenyl)ethylidene]amino\}ethyl)imino]pentan-2one. Bioinorg Chem App. 2015; 2015: 890734.

19. Khaing TA. Evaluation of the antifungal and antioxidant activities of the leaf extract of Aloe vera (Aloe barbadensis Miller). World Acad Sci Engin Tech. 2011; 75(54): 610-612 